\title{
Manahau: Toward an Indigenous Māori theory of value
}

\author{
Jason Paul Mika ${ }^{1}$ (D) Kiri Dell ${ }^{2}$ (D) . Jamie Newth ${ }^{2}$ (D) Carla Houkamau ${ }^{2}$
}

Received: 2 April 2021 / Accepted: 26 January 2022 /Published online: 16 February 2022

(O) The Author(s) 2022

\begin{abstract}
The theoretical challenge posed by this paper is to find a conceptualisation of value for entrepreneurship theory grounded in Indigenous knowledge from a Māori perspective capable of guiding entrepreneurs operating for sustainability and wellbeing. We review Western and Māori theories of value, values, and valuation. We argue that Indigenous concepts of value centre on collective wellbeing as opposed to self-interest, and have spiritual and material elements. The paper proposes a tentative Māori theory of value we call manahau, which combines mana (power, authority, and dignity) and hau (vitality of people, places, and objects). We define manahau as an axiological agent Māori entrepreneurs employ to synergistically negotiate cultural and commercial imperatives to achieve multidimensional wellbeing, human potential, and relational balance. We discuss research which illustrates manifestations of manahau in the Māori cultural ethics of utu (reciprocity) in Māori entrepreneurship and tauutuutu (reciprocity and balance) in Māori agribusiness. We argue that an Indigenous Māori theory of value has implications for entrepreneurship theory and practice.
\end{abstract}

Keywords Value Indigenous entrepreneurship · Aotearoa New Zealand · Mana · Hau • Māori

\section{Introduction}

Entrepreneurship in market economies is evolving in response to changing societal and environmental demands on firms and managers to afford greater credence to nonmarket values of enterprise and economy (Frank et al., 2008). This is reflected in the rise of

Jason Paul Mika

j.p.mika@massey.ac.nz

Kiri Dell

k.dell@auckland.ac.nz

Jamie Newth

j.newth@auckland.ac.nz

Carla Houkamau

c.houkamau@auckland.ac.nz

1 Massey University School of Management, Palmerston North, New Zealand

2 University of Auckland Business School, Auckland, New Zealand 
theoretical developments in social enterprise (De Bruin \& Teasdale, 2019), responsible management (Laasch et al., 2020), inclusive economic development (Gutierrez, 2018; Schulze et al., 2021), economies of wellbeing (Dalziel et al., 2018; Diener \& Seligman, 2004; Wolfgramm et al., 2019), and sustainable enterprise (Colbourne \& Anderson, 2020; Kayseas et al., 2017). In these theoretical developments, fundamental questions of who and what do enterprise serve are challenging scholars and practitioners to reconsider entrepreneurship's values. The tendency has been to search for insights on the value of entrepreneurial activity in the Western intellectual tradition (Wiklund et al., 2011). Yet, Indigenous economies endure, despite generations of inequity, exclusion, and discrimination, as models of resilience and adaptation to colonial intrusions (Colbourne, 2021; Dana, 2015; Shirodkar, 2021; Trosper, 2009). At issue is whether the values that underpin market economies are appropriate in assisting entrepreneurs who must contend with sustainability and wellbeing as managerial challenges.

We believe a useful place to start is to revisit what is meant by value, a concept which lies at the heart of market-based exchange (Podolny \& Hill-Popper, 2004). We consider this issue by exploring meanings of value from an Indigenous perspective based on the knowledge and practices of the Māori people of Aotearoa New Zealand. This paper, therefore, seeks to address the research question-what is a Māori theory of value? The search for a Māori theory of value is culturally situated in the context of Māori entrepreneurship. Thus, we proceed by defining Māori entrepreneurship and illustrate how Māori entrepreneurs appear to use Māori values to negotiate cultural and commercial imperatives generally, and in the sector-specific context of agribusiness. We then review theories of value from Western and Māori perspectives to inform our framework for a Māori theory of value. Finally, we propose a tentative Indigenous theory of value from Māori epistemology, which combines the concepts of mana (power) and hau (vitality) to produce manahau. Manahau, we suggest, may help to explain how value is created and understood, and how cultural and commercial imperatives are negotiated in Māori entrepreneurial philosophy and practice. We conclude with a brief review of the principles of manahau and suggestions for further research.

\section{Māori Entrepreneurship}

\section{An Indigenous Business Paradigm}

Indigenous entrepreneurship is a form of entrepreneurship conducted by Indigenous peoples for purposes beneficial to Indigenous peoples and others, and is increasingly recognised as an emerging paradigm for business across continents (Dana, 2015; Macpherson et al., 2021). Indigenous entrepreneurship research is characterised by Indigenous aspirations for self-determination and sustainable development, and how indigeneity-Indigenous knowledge, culture, language, and institutions-intersect with entrepreneurship (Colbourne, 2021; Mika et al., 2017). Māori entrepreneurship is a localised form of Indigenous entrepreneurship, which originates in Aotearoa New Zealand (Kawharu \& Tapsell, 2019; Zapalska et al., 2003).

Māori entrepreneurship has been defined as "the process by which a Māori person (or people) operating within a Māori world view generates value by identifying and exploiting new products, processes or markets for economic, social and cultural purposes of benefit to themselves, their whānau (family), hapū [subtribe], iwi [tribe] and wider community" 
(Awatere et al., 2017, p. 81). In this view, culture and identity as Māori matter (Mika et al., 2020); an appreciation of knowing, being, and doing as Māori also matter (Mika, 2020), as does value creation beneficial to others (Henry \& Dana, 2019).

Māori entrepreneurship research is increasing in concert with the growing size of the Māori economy (Nana et al., 2021), the growth of tribal enterprise (Barry et al., 2020), mainstream interest in Māori business (Hanita et al., 2016; Harrison, 2020; Potae, 2020), and Māori aspirations for self-determined economic development (Smith et al., 2015). A major focus of Māori entrepreneurship research has been the role of Māori culture in decision making (Awatere \& Harcourt, 2021; Spiller et al., 2020), distinctive forms of enterprise (Amoamo et al., 2018a; Haar et al., 2021), alternative conceptualisations of economy (Amoamo et al., 2018b; Henry \& Dana, 2019), and entrepreneurial ecosystems (Dell et al., 2017). Few studies have, however, empirically examined the performance of Māori firms, save Haar et al. (2021). In a study of 230 New Zealand enterprises, of which 24 were Māori, Haar et al. (2021) found that apart from cultural capital, which they define as 'employees' knowledge and skills towards working with and respecting Māori cultural values" (p. 4), Māori enterprises were similar to non-Māori enterprises. Limitations of the research, however, are the small Māori sample, the absence of firm-level data such as plans and accounts (Smallbone, 2010), and the absence of elucidation on how Māori entrepreneurs (Amoamo et al., 2018a) and Māori managers (Mika \& O’Sullivan, 2014) achieve the kind of balance that Haar et al. (2021) identify as culturally important to Māori. These limitations allude to a question regarding whether Māori culture acts as a constraint or as an enabler in the balancing of cultural and commercial imperatives in business. Achieving balance in business is not straightforward, as one Māori entrepreneur suggests:

So many of our Māori businesses are failing ... we were seeing that generosity was killing them. The desire to give expression to manaakitanga [generosity] with their staff, with their whanau, with the local marae [village complex] ... was just putting such a strain on the businesses ... they weren't giving expression or equal consideration to other kaupapa such as kaitiakitanga [stewardship] and trying to get those balances. (Mika, 2014, p. 6)

Mika (2014) postulated that the ethic of utu (reciprocity) might be acting as a social regulator to mediate against the imbalanced application of manaakitanga (generosity) and its adverse effects. Utu features as an important value in Māori organisational contexts, which Knox (2005, p. 103) defines as "maintaining balance and harmony through 'give and take', reciprocal obligations, honesty in all things, the punishment of wrongdoing, and the exchange of gifts". Further research, however, on utu in Māori enterprise was needed (Mika, 2014).

In a qualitative study of 21 Māori entrepreneurs, Mika (2015) found that participants considered Māori culture both a strength and a weakness. This finding is indicative of the duality of Māori enterprise-evident in the countervailing ideas of protection versus development of Indigenous heritage, in modernity versus contingency theories of Indigenous development, and in the negotiation of cultural (wellbeing) and commercial (wealth) imperatives (Hindle \& Moroz, 2009; Peredo et al., 2004). When asked about whether there is a Māori way of doing business, participants offered two broad responses. On the one hand, they suggest that there is no difference; all businesses must be profitable to survive. On the other hand, self-identifying as Māori implies material differences, most notably a preference for collectivism, an intergenerational imperative, and the use of Māori values (Mika, 2015). At an enterprise level, then, Māori culture is instrumental in Māori entrepreneurship manifesting as an obligation of generosity 
toward one's kin-group, which is socially regulated by an ethic of reciprocity. The implication is that kaupapa Māori (Māori philosophy) and tikanga Māori (Māori culture) underpin an alternative business paradigm, one in which Māori values mediate profit and wealth motives with collective wellbeing to achieve a broader set of outcomes. A sector-specific example of this alternative business paradigm appears in Māori agribusiness.

\section{Māori Agribusiness}

In a study of how Māori agribusinesses manage competing demands, Reid et al. (2019) devise a conceptual framework that identifies five value-drivers of such enterprises: kaitiakitanga (stewardship, sustainability, human-environment reciprocity); whai rawa (intergenerational wealth and legacies); whanaungatanga (positive relationships); manaakitanga (support and generosity); and mana whakahaere (leadership, management, and governance) (Reid et al., 2019). They found that enhancing the mauri (health and wellbeing) of the whenua (land) as an expression of kaitiakitanga (guardianship) is not inconsistent with the profitability imperative of Māori agribusiness.

In subsequent research on the sustainability of Māori agribusiness, Reid et al. (2021) argue that the pre-contact practice of tauutuutu (reciprocity and balance) represents a continuing ethical foundation for contemporary Māori agri-food enterprise that may assist the agro-economy transition to a more sustainable system of land use. In their view, tauutuutu compels communities and firms to invest resources into social and environmental relationships and to ensure returns are equitably distributed. This is because the ethic of tauutuutu contains a social obligation to "make escalating 'investments' that enhance the mana (dignity) and mauri (vitality) of individuals, human families, and related non-human families (land, water, and their offspring), with the expectation that such investments will be returned with equal or greater value at a later date" (Reid et al., 2021, p. 2). An individual's mana, therefore, grows by their capacity to distribute rather than accumulate wealth among the human and nonhuman communities to which they belong. By nonhuman communities we mean te taiao - the environment embodied within Papatūānuku (earth mother) and Ranginui (sky father) and their descendants as elements of nature (Rout et al., 2021). Productivity, innovation, and enterprise are thus driven not by an ethic of satisfying individual want but by a concern for the wellbeing of others (others being both human and nonhuman communities), consistent with Hēnare's (2018) conceptualisation of reciprocal relations between spiritual, ecological, and human societies.

Tauutuutu dictates that such distributions of value are reciprocated by others at some future time who are similarly motivated by the same ethic of mana-enhancing, mauriinducing behaviour. In terms of the environment, tauutuutu operates by obliging society to give back the same or some higher value of what was taken on the basis that "such investments will result in greater returns in the future" (Reid et al., 2021, p. 3). Tauutuutu is thus a "framework for maximising mutually beneficial outcomes amongst humans and between humans and nature by encouraging a cycle of investment and distribution that increases productivity while equitably dispersing returns and encouraging individual entrepreneurship" (Reid et al., 2021, p. 4).

Next we briefly review Western theories of value before turning our attention to Māori theories of value to help explain these observances of value creation, reciprocity, and balance in entrepreneurship from a Māori perspective. 


\section{Western Theories of Value}

\section{Hedonism}

The definition of theory in Western epistemology draws on bodies of knowledge or a system of ideas intended to explain a particular domain based on general principles (Lidell \& Scott, 2010; Russell, 2004). Western theories have often been criticised as biased against non-Western peoples and nations (Marglin, 1990). Indeed, unequal power relations, especially between the colonised and colonisers, have perpetuated "the Eurocentric myth that the West supplies 'the theory' and the Rest but the case studies and empirical data" (Hobson \& Sajed, 2017, p. 560). In response, Mignolo calls for "epistemic disobedience" as a way to create the conditions "to delink from the illusion of the zero point epistemology" (Mignolo, 2009, p. 160). This implies rejecting Western universalism and acknowledging world views other than one's own, opening the way for theorising from Indigenous perspectives (Huambachano, 2015; Watene \& Drydyk, 2016).

According to Behrman (1988, pp. 5-6), “[a]ll economic systems are based on values", with the values of individualism and utilitarianism forming the ethical roots of capitalism. Individualism holds that each person must be free to achieve perfection, while utilitarianism maintains that each person seeks to minimise pain and maximise pleasure. This maxim originates from Bentham's hedonistic assertion of "the greatest good for the greatest number" (Behrman, 1988, p. 12). Behrman (1988, p. 13), then, argues that hedonism, defined as "unconstrained individual pleasure", is what every individual and society should seek to maximise. Over time, the concept of pleasure has been narrowly redefined to mean the enjoyment of material goods with monetary value. Thus, the hedonistic goal of maximising societal pleasure becomes maximising growth in which only goods and services that attract payment count (Behrman, 1988). In this perspective, hedonic value has several proxies: equating with growth measured in terms of gross domestic product at the level of the economy (Friedman, 1982; Stiglitz et al., 2010); equating with maximising shareholders' wealth at the firm-level (Gugler, 2001; Healy, 2003); and profit maximisation at the level of the entrepreneur (Parker, 2009).

Within market economies we find that entrepreneurship and innovation emphasise hedonic conceptualisations of value, in which consumers, on the one hand, are compelled to maximise utility (the use and usefulness) from any given object (a good or service) and producers, on the other hand, are driven to offer such value on the most competitive terms possible. Value is thus derived in two main ways: value-in-use (what one can do with or because of an object) and value-in-exchange (what one can get for an object), typically quantified in monetary terms (Podolny \& Hill-Popper, 2004). In this view, value is reduced to an objectifying assessment of functional and abstract characteristics to facilitate product comparison and consumer choice on cognitive, emotive, or aesthetic terms (Podolny \& Hill-Popper, 2004). The unencumbered pursuit of one's sense of value is the height of an economic system built upon a principle of self-interest (Smith, 1991[1776])—hedonism, in other words (Ryan \& Deci, 2001).

One of the problems with this view, we argue, is that hedonic conceptualisations of value are complicit in a system that perpetuates ecological degradation and extreme poverty (Roser \& Ortiz-Ospina, 2019; United Nations, 2019). Capitalism's response has been more of the same kind of enterprising activity (maximising economic value), only with a more responsible approach (Laasch et al., 2020), a diversity of objects (Weijers \& Mukherjee, 2016), or more sustainable methods (Hall, 2019). Yet, prevailing Western market-based 
entrepreneurship coheres around values which prioritise obtaining wealth, typically measured in monetary terms.

\section{Valuation, Value and Values}

In the Western episteme, valuation is a processual enactment of value centring on measurement, ascribing objects static and agentive qualities typified in mediums of exchange and stores of value associated with the concept of capital (Bourdieu, 1986; Hicks, 1939). Valuation of economic activity has, hitherto, excluded environmental considerations, particularly negative externalities (Barrow, 2006; Stiglitz et al., 2010), but recent attempts at valuing ecological systems (Costanza et al., 1997; Costanza et al., 2017), human development (Anand \& Sen, 2000; Ranis et al., 2000), and wellbeing (Grimes et al., 2012; Weijers \& Mukherjee, 2016) are altering this convention. Valuation facilitates maximising behaviour of market-based enterprise, expressed in the inexorable pursuit of economic value as highorder morality (Suddaby et al., 2017). The end-game here is, whomever controls valuation as a process determines what is of value and what is valued, which, taken together, allude to the social determinants of value (De Munck \& Lyna, 2015).

Conti (2010) suggests that quality, which characterises an entity or object, is valueless until value is perceived, generated, and exchanged through the concept of relations. Economic value, for example, is constituted in economic relations, spiritual value manifests within noneconomic relations, and scientific or aesthetic value appears in the case of relations between humans and nature or between humans and objects (Conti, 2010). Thus, according to Conti (2010), it is relations that transform quality into value, which resonates with the emphasis Indigenous peoples place on human and nonhuman relationships (Rout et al., 2021).

Sen (2003, p. 115) regards value as "the practical attitude of some agent assumed towards an object or an intentional act in relation to his feelings, desires, interests, purposes and needs". Value as a verb, according to Sen (2003, p. 116), means "the act of evaluation"; in other words, the process of determining the value of an object or act by reference to human needs and aspirations. Sen (2003) suggests that adherence to tribal social customs, which are spiritually bestowed and transmitted by ancestors through the generations, counts as tribal morality intended to perpetuate the tribe in peaceful coexistence with nature. According to Sen (2003, p. 118), the highest value is overall tribal wellbeing, which is not "personal unity with the Supreme", but "to be integrated with the nature in perfect harmony and peace".

There are, of course, exemplars of business activity which generate broader forms of value (Dacin et al., 2011). One such example is social entrepreneurship, which extends entrepreneurship in the social sphere to consider accountability to a range of stakeholders (Ratten, 2007). Models of social entrepreneurship that consider the collective human impact of entrepreneurial activity have emerged as a form of institutional logic to assist managers and firms to make sense of the quandary presented by sustainability-how to balance social, economic, and environmental considerations (Crane et al., 2008; Kickul \& Lyons, 2020). Yet, the social entrepreneurship literature suffers from a distinct absence of a compelling culturally constituted basis for forming judgements about what is good and who (and what) should benefit from entrepreneurial activity. We contend that there ought to be some meaningful principle by which managers and entrepreneurs can reach such accommodations aside from, or in addition to, deferring to some higher order intelligence 
(divinity), computational intelligence (artificial), or the trade-offs implicit in the sustainability supposition.

While we are aware that any account of Western perspectives, delimited out of necessity here, glosses over fundamental points of tension and difference, our goal is to emphasise that Western theories of value offer an incomplete explanation as they provide little or no account of Indigenous perspectives. For an expanded account of Western theories of value, please see Dobb (1973). Moreover, social entrepreneurship, while increasingly aligned with Indigenous perspectives (Curry et al., 2016), does not acknowledge issues of power, culture, and self-determination, which are recognised as crucial to Indigenous peoples (Mika et al., 2017).

\section{Indigenous Māori Theories of Value}

\section{Te Ao Māori-The Mãori World View}

Māori are one of many Indigenous peoples across the world who comprise a vast array of some 5000 cultures, languages, and lifeways (Cole, 2017; Katene \& Taonui, 2018; Lightfoot, 2016; World Bank, 2019). While Māori share much in common with other Indigenous peoples, they have a distinct language, culture, history and traditions, which shape their orientation, existence, and potential. Yet, there is commonality at an epistemological level in terms of how Indigenous world views or paradigms inform conceptualisations of value (Cole, 2017; Cunningham \& Stanley, 2003).

The first principle of an Indigenous paradigm is that everything has value because everything is connected with everything else; the interdependency of all things requires this (Cole, 2017; Harris \& Wasilewski, 2004; Huambachano, 2015; Verbos et al., 2017; Wilson, 2008). This is known because the wisdom of our elders expressed in tribal epistemologies informs us (Davies, 2011; Durie, 1999; Knudtson \& Suzuki, 1997; Kovach, 2010; Mika, 2016). The second principle of an Indigenous paradigm is one of balance, the maintenance of which is evident in the enactment of reciprocity, intimated in te ao Māori (the Māori world view) by the concepts of hau (spirit of the gift) and utu (the practice of reciprocal relations), which occur in cultivation and harvests, and ceremonial, commercial, and humanitarian exchanges (Harris \& Wasilewski, 2004; Hēnare, 2018; Mauss, 2002; Polanyi, 1944). A third principle of Indigenous paradigms is the immortalisation of physical beings evident in the transference of energy from one form to another (from embodiment to deification), the endlessness of time, and the circular flow of energy and experience (Best, 2005; Hēnare, 2001; Reed \& Calman, 2021). Value is embodied and effected in lifeways consistent with indigeneity (Durie, 2002; Harris \& Wasilewski, 2004; Mead, 2003).

Value from an Indigenous perspective, then, is ubiquitous; it exists in all things. It is material, immaterial, intrinsic, extrinsic, intertemporal, transformative, and effectuating (Berwick, 1995; Best, 2005; Colbourne, 2017). This makes an Indigenous view of value somewhat incomprehensible because it is boundary-less, amorphous, and without end. Yet, value is discernible through subjectifying consciousness, the possession of which transfers from the person to the group through culturally encoded lifeways, narratives, and values (Bargh, 2012; Bavikatte et al., 2010; Foucault, 1972). Values in this view represent human attempts at giving material form, function, and boundaries to the immaterial, extricating innate ethicality from what is valued (Cram, 1993; Hudson, 2005; Powick, 2003).

L. T. Smith (1999) argues that Indigenous peoples have long been oppressed by theory, mainly because anthropological methodologies, which study Indigenous cultures, were 
never neutral. She asserts that accentuating Indigenous theory is an integral part of decolonising research. In Aotearoa New Zealand, G. H. Smith (1992) introduced the notion of kaupapa Māori theory with his inclusion of the Western word theory - a deliberate act on his part. His intention was to show that Indigenous people have theories of their own that have validity and legitimacy for them (Smith et al., 2012). Māori theory development is grounded in experience and knowledge acquired culturally, spiritually, religiously, scientifically, and in other ways (Te Momo, 2007). Māori theory is thus embedded within Māori epistemology, whose foundation consists of te ao Māori (Marsden, 1992), mātauranga Māori (Māori knowledge) (Hikuroa, 2017), kaupapa Māori (Māori philosophy) (Smith et al., 2012), tikanga Māori (Māori values) (Mead, 2003), and te reo Māori (Māori language) (Higgins et al., 2014).

Mead (2012) explains that Māori knowledge and Māori theory-building are processes of recovering mātauranga Māori in all its forms and adapting new knowledge from an Indigenous foundation with the addition of, and exposure to, Western and non-Western knowledge and its exponents. This broad view of mātauranga Māori spotlights the transdisciplinarity inherent within Māori and Indigenous theorising, which legitimises rather than constrains non-traditional knowledge generation and theory-building (Cole, 2017).

In the academy, Māori have been working to create a dialogue between mātauranga Māori and Western science (Henry \& Pene, 2001; Watene, 2016). For example, in biotechnical research, Hudson et al. (2010) devise a dialogic process around which to frame the Indigenous episteme along five reference points: (1) contemporary Māori experience; (2) mātauranga Māori; (3) Māori experiences of colonisation; (4) Treaty of Waitangi perspectives; and (5) science-based perspectives. Within these cultural cues, Māori theory evolves from pre-contact knowledge (Royal, 2003), Māori experience of and responses to colonial power, and the adaptation of Western knowledge to Māori development purposes (Durie, 2003). In light of this meshing of Māori and Western knowledge, a Māori theory of value seems essential to understanding Māori enterprise (Mika et al., 2019).

Although there is no Māori word that is equivalent to the English word 'value', Marsden, cited in Royal (2003), suggests that 'taonga' (treasures), or, more precisely, 'taonga tuku iho' (treasures handed down from one generation to another), may be a close substitute. Craig et al. (2012) unpack the dimensions of taonga in accounting theory. They define taonga as "all things highly prized, tangible and intangible, material and spiritual" (Craig et al., 2012, p. 1036). Taonga, in this sense, encompasses language, culture, rights and interests, in relation to past, present, and future generations.

According to Hēnare (2018), Māori distinguish between ownership and possession of taonga by two possessive particles, $t \bar{o}$ (indicating ownership) and $t \bar{a}$ (indicating possession). While conceptually derived from Māori knowledge, taonga assumed constitutional significance in the formation of New Zealand as a colonial state by the British Monarch in the Treaty of Waitangi of 1840 (Orange, 1987). Under the treaty, Māori were guaranteed "exclusive and undisturbed possession" of their property (real and personal), while in the Māori text of the treaty, the same promise was written as retaining tribal self-determination over all of their "taonga" (Kawharu, 1989, p. 317). Waitangi Tribunal claims concerning Crown breaches of the treaty affirm a view of taonga as inclusive of "all dimensions of a tribal group's estate, material and non-material" (Kawharu, 1989, p. 320). An example of the non-materiality of taonga is the claim that the Māori language is a taonga, essential to Māori identity, dignity, and authority, and its decline represented a breach of Crown obligations under the treaty to protect the language (Durie et al., 1986).

In a treaty claim concerning Māori cultural and intellectual property rights known as the 'Indigenous flora and fauna claim' (or Wai 262, short for the Waitangi Tribunal claim 
number under which the claim was lodged), the tribunal recommends that Māori rights and interests in taonga be recognised in Crown law and policy (Williams et al., 2011). Usefully, the tribunal disaggregates taonga into three forms: (i) taonga-natural resources consisting of lands, waters, plants, and wildlife; (ii) taonga works - tangible and intangible manifestations of mātauranga Māori including the artistic, cultural, and intellectual works, and technologies and tools of carvers, weavers, writers, and musicians; and (iii) taonga species - the unique properties of Indigenous flora and fauna, including genetic and biological resources and their uses (Williams et al., 2011). Hudson et al. (2021) draw on this delineation of taonga to devise guidelines for genomic research of taonga species, which suggest that the commercialisation of this research involves a confluence of cultural, commercial, and science imperatives. While tangible and intangible things of value such as taonga tuku iho are culturally significant to Māori, intellectual property law has inadequately protected Indigenous knowledge (Mead, 1994), but this is gradually changing (Ahu et al., 2017).

In Aotearoa New Zealand, the process of calculating economic value has been applied to quantifications of the value of Māori land (Kingi, 2008; Winiata, 2008), Māori fisheries (Bargh, 2014; Campbell, 1999; Rout et al., 2018), Māori economies (Nana et al., 2021; Smith et al., 2015), treaty settlements (Meijl, 2012; Tawhai \& Gray-Sharp, 2011; Wheen \& Hayward, 2012), the Māori language (Higgins et al., 2014; Meade, 2021; Roskruge et al., 2017), and tribal resources (Awatere et al., 2017; Barry \& George-Neich, 2019; Winiata, 1988). Several themes are evident in these instances of enculturated valuation: first, the minimisation of Māori rights and interests in sites of contestation between Māori and nonMāori, most aptly illustrated in treaty settlements; second, the presupposed application of non-Māori methodologies to Māori valuation, especially in economic activity; and third, the difficult but essential challenge of creating Māori valuation methodologies from Māori and non-Māori knowledge.

\section{Toward a Māori Theory of Value}

\section{Māori and Western Values}

Western scientific tradition has emphasised the objectifying consciousness of value to transform it from a matter of personal perception to having materiality in group relations, represented by the interactivity among markets, firms, and entrepreneurs (Coase, 1937; Hayek, 1945; Schumpeter, 2000). Binary differentiations between Māori and non-Māori must be used cautiously because they belie the cultural continuity and adaptive capacity of Māori entrepreneurs to capitalistic modalities (Frederick \& Henry, 2004; Petrie, 2006; Reid \& Rout, 2016). Yet, a commonly accepted extrinsic measure of value (profit, for example) is the ultimate in Western consciousness, whereas a commonly accepted intrinsic measure of value (hau, for example) is the ultimate in Indigenous consciousness. Within an Indigenous paradigm, values provide a culturally constituted framework for deciphering value, accounting for its existence and transmodality from one form to another. Values are contextually and temporally defined, resonating with the essence of what is valued (Craig et al., 2012; Harmsworth, 2005).

Te ao Māori offers a compelling perspective of value, values, and valuation derived from its cosmological traditions about creation, emancipation, and enlightenment (Durie, 2011; Reed \& Calman, 2021; Royal, 2003). This tradition stretches from the eternal darkness of the embrace of Ranginui (sky father) and Papatūānuku (earth mother), their eventual separation by their conflicted sons, the gods of the elements, which cloaked the Earth 
in light, to the fashioning of the first human, a woman, from clay (Buck, 1958; Marsden, 1992; Royal, 2005). We derive from this cosmology an array of values that retain their potency amidst modernity through complex pluralities, most profoundly starting with whakapapa, genealogies connecting humanity with nonhuman actors, and, ultimately, with the cosmos itself (Amoamo et al., 2018a, 2018b; Black et al., 2012).

In the pantheon of te ao Māori, we draw attention to several values: the value of kotahitanga (unity) and the interrelatedness of all things; whakapapa (genealogy), the value of unbroken lines of descent from the heavens to humanity; mana (power), the value of vestiges of divine power, authority, and responsibility, which are imbued within all things, human and nonhuman; kaitiakitanga (guardianship), protecting kin-people and planetfor all are kin; whanaungatanga (kinship), establishing and maintaining familial relations as an organising principle; manaakitanga (generosity), caring for others with kindness; and wairuatanga (spirituality), the constant duality of all things (Barlow \& Wineti, 1991; Mead, 2003). These values intimate what Māori value: identity, origins, and purpose defined in terms of relationality (Williams et al., 2011).

Next we examine two Māori values—mana and hau—and reconstitute them in combination as manahau to denote a concept of value from a Māori perspective that may help explain why reciprocity remains an active agent in Māori entrepreneurship.

\section{Mana}

Mana is a complex concept, but is broadly interpreted as power, authority, prestige, honour, status, and influence (Moorfield, 2011), acquired by divine intercession, and enhanced through collectively favourable human action which, along with the principle of tapu (sanctity), regulated social and economic relations in pre- and post-contact Māori society (Love \& Waa, 1997; Waa \& Love, 1997). Mana can be amplified by acts of bravery and kindness that enhance the mana of others, and, in so doing, enhance the mana of the person or people carrying out such acts (Mahuika, 1981). Taking the concept of mana as the central theme, Hēnare $(2011,2014,2016)$ proposes an 'economy of mana' as a kaupapa Māori theory of enterprise and economy that prioritises relational equilibrium. Building on Hyden's (1980) concept of affective economies and Mauss's (2002) idea of gift economies, Hēnare (2011) defines economy of mana as an "holistic mode of business" (p. 271). In the mana economy, traditional Māori values, which have evolved over a thousand years of Indigenous economic activity in Aotearoa, suggest the purpose of economy and enterprise is a good life, constituted not in private wealth but in "spiritual, environmental, cultural, and economic wellbeing" (Hēnare, 2011, p. 269). Hēnare (2011) equates the mana-oriented firm with social enterprise because of the capacity of such firms for non-capitalist activity.

Dell et al. (2018, p. 56) extend Hēnare's work by defining an economy of mana as "an economic system in which decisions regarding investment, production, consumption, and wealth distribution are influenced by the interplay of mana-enhancing interactions between people and the environment". Dell et al. (2018) identify four forms of mana: (1) mana atua-divine power derived from the gods; (2) mana tippuna-ancestral power and traits; (3) mana whenua-power and authority from and over land; and (4) mana tangata-power from personal attributes and actions. An economy of mana orients behaviour toward the wellbeing of others, where economy and enterprise are culturally and ecologically embedded processes of value creation and sharing, reinforcing and regenerating the central virtue of the social system itself - that is, "relational equilibrium" and collective wellbeing (Dell, 2017, p. 89). Yet, Dell et al. (2018) note that the theoretical and practical groundwork is 
still to be done to precisely articulate the institutions of an economy of mana. One of the challenges is to understand how Māori entrepreneurs negotiate cultural and commercial imperatives drawing on a mana-enhancing orientation. The Māori concept of hau may provide some guidance.

\section{Hau}

Hau is a metaphysical concept interpreted as the vitality of a person, place, or object (Moorfield, 2021), embodying the spiritual essence and material effect of gift-giving on relations between people (Best, 1909). The concept of hau captured the imaginations of Western scholars, most notably Best (1909), Firth (1929), Mauss (2002), Sahlins (1972), and LéviStrauss (2014), who were intrigued by its centrality as an element of a pre-capitalist system of reciprocal exchange. Indigenous scholars, including Hēnare (2018), Stewart (2017), and Nicholson (2019), have contested these analyses as misappropriations and misrepresentations of Indigenous knowledge, where the concept of hau is 'scientised' according to Western ideologies, sensibilities, and ends, stripping hau of its indigeneity and spiritual origins (Mika, 2012). Hēnare (2018), for instance, argues that Best's (1909) injudicious editing of the translation of letters he received from Tāmati Ranapiri, in which Ranapiri explains the meaning of hau, resulted in an analytical error repeated by later scholars, including Mauss (2002). Best's misinterpretation, Hēnare (2018) contends, is that the object itself possesses spiritual energy, when it is more likely that Ranapiri meant that the life force of the donor is conveyed within the gift and retains its potency after the gift is received.

Hēnare (2018) concludes that the explanation Ranapiri gives of hau alludes to an economy of mana, which sustains four wellbeings-spirituality, environment, kinship, and economy — which are constitutive of four types of capital: spiritual capital, ecological capital, kinship capital, and economic capital. When the four wellbeings and four forms of capital are working in combination, they do so according to a system of reciprocity between spiritual, ecological, and human societies. What Hēnare leaves unexplained is how this system of reciprocity based on the notion of hau functions in the spiritual, ecological, and human realms.

Nicholson (2019) responds to the call for Māori voices to rejoin the discourse on hau as 'the spirit of the gift' with its Māori philosophical roots. She does this by foregrounding the oral and written literature of Māori scholars, challenging Eurocentric analyses of hau, and reframing the interpretation of Māori concepts within Māori epistemology (Nicholson, 2019). Nicholson (2019) traverses the whakapapa (origins) of hau as an elemental energy of creation from which heaven and earth emerge, imbuing phenomena with this same cosmic vital essence, which functions as a reciprocal flow of life-giving energy deserving of reverence and protection. Stewart (2017) sees hau as a cosmic mediator between te ao wairua (spiritual realm) and te ao mārama (physical realm), with hau constantly aspiring toward hau-ora (states of life and wellness) and away from hau-mate (the onset and state of death). Hau, according to Nicholson (2019), is an indivisible element of an assembly of cosmic energies, consisting of mauri (life force), wairua (spirit), and mana (power). Hau is the agent imbuing all things, animate and inanimate, with mauri as the life force, denoting the vitality of mauri (Royal, 2003). Wairua refers to a person's spirit, with hau the vitality of the spirit and the conduit by which wairua moves between te ao wairua and te ao mārama (Hēnare, 2003). In respect of mana, the hau of a thing or person is maintained and transformed by mana as spiritual power and authority, expressed through human agency (Dell et al., 2018). Nicholson (2019) reveals rituals of whāngai hau—nurturing hau 
by acknowledging the bounty of nature through reciprocal offerings between humans and nature, such as returning the first fish of the catch or allowing the steam from the cooking of food to be consumed by the stars. Hau, in this sense, exerts moral intention and invokes reciprocal exchange toward states of balance and maintenance of hau-ora (wellbeing) in the relations between the human, ecological, and spiritual worlds (Hēnare, 2003).

\section{Manahau}

Sustainability is vital to commercial endeavour because of the exhaustibility of safe and secure natural resources, but a galvanising ethical principle to help entrepreneurs integrate social, economic, and environmental wellbeing remains elusive (Anand \& Sen, 2000; Everard, 2011). By grounding entrepreneurship in Indigenous values, Indigenous entrepreneurs are reframing business in an holistic way, rejecting the customary-commercial binary in favour of duality, adaptation, and hybridity (Amoamo et al., 2018a; Galperin Bella et al., 2021; Mika et al., 2017). Yet, a recurring dilemma within Indigenous entrepreneurship persists: how do Indigenous entrepreneurs reconcile cultural (wellbeing) and commercial (wealth) imperatives? We suggest that mana and hau have important theoretical contributions to make.

Mana provides the spiritual and physical power and agency for Māori entrepreneurs to define, deliver, and share value in ways consistent with a Māori world view, with mana manifesting as a kin-network of mana atua (authority of the gods), mana whenua (authority of the land), mana moana (authority of the seas), and mana tangata (authority of the people). While all people possess mana, it can be enhanced through favourable human action, by, for example, securing the wellbeing of others characterised as a mana-enhancing orientation and behaviour. Thus, mana is both means and ends in Indigenous entrepreneurship, enabling an Indigenous entrepreneurial orientation (Mrabure et al., 2018) and functioning as a measure of enterprise success (Mika et al., 2020).

For its part, hau represents the metaphysical vitality that coheres in taonga, inclusive of valued natural capital, the augmented value of taonga works, and the cultural, physical, and intellectual properties of taonga species. Hau imbues relationships between people and planet, and spiritual and physical energy, creating an obligation of reciprocal exchange for shared wellbeing (Nicholson, 2019). The value of hau is relational, reciprocal, and in its outcomes.

When combined, mana and hau form a new concept-manahau-that integrates Hēnare's (2014) notion of mana as a predicate for affective economic activity and Nicholson's (2019) hau as a metaphysical concept denoting the vitality inherent in gift exchange processes, on which Hēnare (2018) also writes (see Fig. 1). We, therefore, define manahau as an axiological agent Māori entrepreneurs employ to synergistically negotiate cultural and commercial imperatives to achieve multidimensional wellbeing, human potential, and relational balance in multiple sites, sectors, and scales. Manahau orients entrepreneurship toward mana-enhancing behaviour, demonstrated by reciprocal exchanges of taonga as valued objects-material and immaterial. The success of manahau is indicated by the extent to which the mana of other entities is enhanced and is reciprocated.

Māori entrepreneurship research in various sectors suggests that when encountering multi-objective managerial contexts, Indigenous entrepreneurs negotiate cultural and commercial imperatives in ways consistent with manahau. This is apparent in Māori agribusiness (Reid et al., 2021; Rout et al., 2020; Sciascia et al., 2019), the kaitiaki-centred business models of Māori marine-based enterprises (Reid \& Rout, 2020; Rout et al., 2019), the 


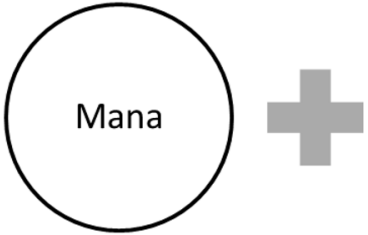

Mana as "status, prestige and credibility" (Hēnare, 2018, p. 451) is embodied in multiple states, manifesting as mana-enhancing behaviour creating relational balance (Dell et al., 2018)

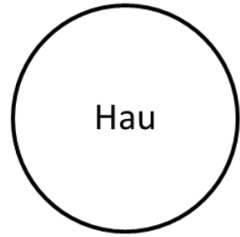

Hau is the intrinsic and ascribed "spirit of gift exchange or the ethic of generosity" (Hēnare, 2018, p. 451) imbued within taonga creating reciprocal obligations

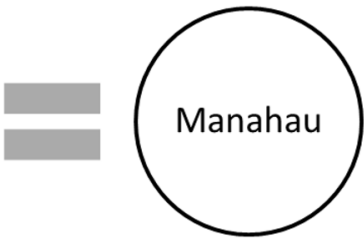

Manahau is theorised as an axiological agent Māori entrepreneurs use to synergistically negotiate cultural and commercial imperatives to achieve multidimensional wellbeing

Fig. 1 Constitutive elements of manahau —a Māori theory of value

commercialisation of genomic research of taonga species (Hudson et al., 2021) and in the economics of Māori identity (Houkamau et al., 2019; Houkamau \& Sibley, 2019). In this paper, however, we focus on Māori entrepreneurship and Māori agribusiness. Although these examples do not constitute empirical evidence in the strict sense, we suggest that these studies manifest the presence, and indicate the operation, of values associated with manahau. Because manahau is presented here as a theoretical model, we anticipate future studies will ground this model in empirical data, which may in turn further refine the theory.

Three main insights about manahau are apparent in the examples we have drawn from Māori entrepreneurship and Māori agribusiness. First, reciprocity expressed as utu in Māori entrepreneurship and tauutuutu in Māori agribusiness is posited as an explanation for achieving balance in obligations between the commerciality of the firm and the wellbeing of human and nonhuman communities. Second, the relationship between the firm, the community, and the environment is described in holistic terms rather than as separate entities, consistent with the view that all things, animate and inanimate, are related, thereby establishing an interdependency for their mutual wellbeing which is catalysed by reciprocity. Third, the values that drive reciprocal exchange are primarily mana and the hau of taonga as valued objects. We suggest, therefore, that manahau is both means and ends in value creation processes where value is defined as collective wellbeing, human potential, and relational balance. The potential for manahau to transform entrepreneurial values and practice in market economies and enterprise generally remains to be seen.

\section{Conclusion}

This paper set out to discuss Western and Māori theories of value to better understand how Indigenous Māori entrepreneurs achieve sustainable development and negotiate cultural and commercial imperatives in business. The logic of the capitalist firm relies on a singular focus on the utilitarian and hedonic ethics of self-interest, market-based exchange, and wealth accumulation. The logic of the sustainable firm widens this objective set to include economic, social, and environmental aims, but an alternative principle to aid entrepreneurs in negotiating these imperatives is missing. We found that Western theory categorises value as having both subjective and objective meaning as value-in-use and value-in-exchange, which rely on quantitative valuation processes that produce monetary representations of 
value. In the Māori economy, Māori entrepreneurship is evolving a way of doing business grounded in Māori knowledge, but integrating within this elements of Western knowledge. Taonga is the nearest equivalent Māori word for the English word 'value'. Taonga refers to objects of value, which have spiritual and physical manifestations as natural capital, augmented taonga works, and taonga species. The Māori values of mana and hau are proffered as explaining value in Māori entrepreneurship. We define mana as power and authority with divine intercession and human agency, which manifests as an economy of mana intended to create collective wellbeing, human potential, and relational balance. We define hau as an intrinsic vitality conveyed in the reciprocal exchange of taonga that has spiritual and material significance for social and economic relations between human and nonhuman communities. We introduce manahau as a new concept that combines Hēnare's (2014) notion of mana as a predicate for affective economic activity and Nicholson's (2019) interpretation of hau as a metaphysical concept denoting the vitality inherent in gift exchange processes. Manahau represents a tentative step toward a Māori theory of value offering insight into how Māori entrepreneurs negotiate cultural and commercial imperatives toward multidimensional wellbeing, human potential, and relational balance. Research on Māori entrepreneurship across several sectors, sites, and scales indicates that a synergistic, non-binary approach rather than a trade-off mentality and practice is evident, but further research is needed. Four suggested directions for this research are (1) the observation of entrepreneurial practice to discern evidence of manahau in decision making; (2) the development of a quantitative expression of manahau; (3) the evaluation of qualitative and quantitative expressions of manahau in practice; and (4) how non-Māori and non-Indigenous managers and scholars might be guided by manahau.

\section{Glossary}

ao world, daylight

Aotearoa land of the long white cloud, New Zealand

hau vitality of people, places, and objects

hau-mate unhealthy, unwell, spiritless, lifeless

hau-ora wellbeing, wellness, healthy

iwi tribe, nation

kaitiakitanga guardianship, stewardship

kaupapa Māori Māori philosophy

kaupapa purpose, philosophy

kawa customs and procedures

kotahitanga unity

mana atua power and authority of the gods

mana moana power and authority of the water

mana tangata power and authority of people

mana whenua power and authority of the land

mana power, authority, prestige, status, influence

manaakitanga generosity

Māori the Indigenous people of Aotearoa New Zealand

mâtauranga knowledge

mauri life force, ethos 


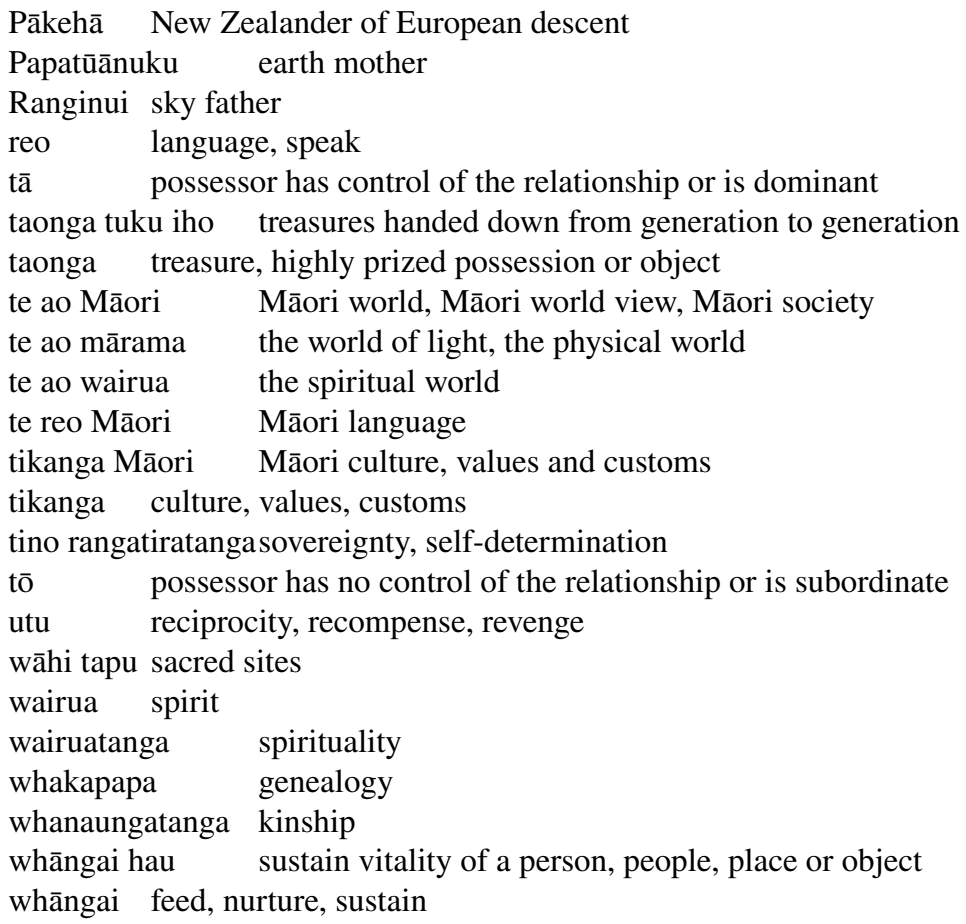

Acknowledgements We acknowledge Ngā Pae o te Māramatanga (New Zealand's Māori Centre of Research Excellence) for their funding support and technical assistance. In particular, we thank Dr. Shaun Awatere, the late Associate Professor Mānuka Hēnare and Professor Chellie Spiller, Whai Rawa (Māori economies) research theme leaders at Ngā Pae o te Māramatanga for their advice.

Funding Open Access funding enabled and organized by CAUL and its Member Institutions.

\section{Declarations}

Conflict of Interest The authors declare that they have no conflicts of interest.

Open Access This article is licensed under a Creative Commons Attribution 4.0 International License, which permits use, sharing, adaptation, distribution and reproduction in any medium or format, as long as you give appropriate credit to the original author(s) and the source, provide a link to the Creative Commons licence, and indicate if changes were made. The images or other third party material in this article are included in the article's Creative Commons licence, unless indicated otherwise in a credit line to the material. If material is not included in the article's Creative Commons licence and your intended use is not permitted by statutory regulation or exceeds the permitted use, you will need to obtain permission directly from the copyright holder. To view a copy of this licence, visit http://creativecommons.org/licenses/by/4.0/.

\section{References}

Ahu, T., A. Whetu, and J. Whetu. 2017. Mātauranga Māori and New Zealand's intellectual property regime: Challenges and opportunities since Wai 262. New Zealand Intellectual Property Journal 8 (2017): 79-91. 
Amoamo, M., K. Ruckstuhl, and D. Ruwhiu. 2018a. Balancing indigenous values through diverse economies: A case study of Māori ecotourism. Tourism Planning \& Development 15 (5): 478-495. https:// doi.org/10.1080/21568316.2018.1481452.

Amoamo, M., K. Ruckstuhl, and L. Carter. 2018b. Framing the Māori economy: The complex business of Māori business. MAI Journal 7 (1): 66-78. https://doi.org/10.20507/MAIJournal.2018.7.1.6.

Anand, S., and A.K. Sen. 2000. Human development and economic sustainability. World Development 28 (12): 2029-2049. https://doi.org/10.1016/S0305-750X(00)00071-1.

Awatere, S., and N. Harcourt. 2021. Whakarite, whakaaro, whanake whenua: Kaupapa Māori decision-making frameworks for alternative land use assessments. In Kia whakanuia te whenua: People, place, landscape, ed. C. Hill. Mary Egan.

Awatere, S., J.P. Mika, M. Hudson, C. Pauling, S. Lambert, and J. Reid. 2017. Whakatipu rawa mā ngā Uri whakatipu: Optimising the 'Māori' in Māori economic development. AlterNative 13 (2): 1-9. https:// doi.org/10.1177/1177180117700816.

Bargh, M. 2012. Rethinking and re-shaping indigenous economies: Māori geothermal energy enterprises. Journal of Enterprising Communities 6 (3): 271-283. https://doi.org/10.1108/17506201211258423.

Bargh, M. 2014. A blue economy for Aotearoa New Zealand? Environment, Development and Sustainability 16 (3): 459-470. https://doi.org/10.1007/s10668-013-9487-4.

Barlow, C., and E. Wineti. 1991. Tikanga whakaaro: Key concepts in Maori culture. Oxford University Press.

Barrow, C.J. 2006. Environmental management for sustainable development. 2nd ed. Routledge.

Barry, P., \& George-Neich, Z. (2019). Iwi investment report 2018. https://www.tdb.co.nz/wp-content/uploa ds/2019/02/TDB-2018-Iwi-Investment-Report.pdf

Barry, P., Graham, L., \& Barry, M. (2020). Iwi investment report 2019. https://www.tdb.co.nz/wp-content/ uploads/2020/02/Iwi-Investment-Report-2019.pdf

Bavikatte, K., H. Jonas, and J. von Braun. 2010. Traditional knowledge and economic development: The biocultural dimension. In Traditional knowledge in policy and practice: Approaches to development and human well-being, ed. S.M. Subramanian and B. Pisupati, 294-326. United Nations University Press.

Behrman, J.N. 1988. Values underlying capitalism. In Essays on ethics in business and the professions, 5-18. Prentice Hall.

Berwick, P. 1995. Concepts of time and pastoral care within Maori businesses. Department of Management Systems, Massey University.

Best, E. 1909. Maori forest lore: Being some account of native forest lore and woodcraft, as also of many myths, rites, customs, and superstitions connected with the flora and fauna of the Tuhoe or Ure-Wera District. Transactions and Proceedings of the New Zealand Institute 42 (III): 433-481 https://paper spast.natlib.govt.nz/periodicals/TPRSNZ1909-42.2.2.52.

Best, E. 2005. Māori religion and mythology: An account of the cosmogony, anthropogeny, religious beliefs and rites, magic and folk lore of the Māori folk of New Zealand. Te Papa Press.

Black, T., D. Bean, W. Collings, and W. Nuku. 2012. Conversations on mātauranga Māori. New Zealand Qualifications Authority https://www.nzqa.govt.nz/assets/Maori/ConversationsMMv6AW-web.pdf.

Bourdieu, P. 1986. The forms of capital. In Handbook of theory and research for sociology of education, ed. J.G. Richardson, 241-258. Greenwood Press.

Buck, P. 1958. The coming of the Maori. 2nd ed. Maori Purposes Fund Board.

Campbell, D. 1999. Valuation of indigenous fisheries 43rd Annual Conference Australian Agricultural \& Resource Economics Society. Christchurch https://ageconsearch.umn.edu/record/123792/files/Campb ell.pdf.

Coase, R.H. 1937. The nature of the firm. Economica 4 (16): 386-405 https://www.jstor.org/stable/765011.

Colbourne, R. 2017. An understanding of native American entrepreneurship. Small Enterprise Research 24 (1): 49-61. https://doi.org/10.1080/13215906.2017.1289856.

Colbourne, R. 2021. Indigenous entrepreneurship. In The Palgrave handbook of minority entrepreneurship, ed. T.M. Cooney, 319-348. Palgrave.

Colbourne, R., and R.B. Anderson. 2020. Indigenous wellbeing and enterprise: Self-determination and sustainable economic development. Routledge.

Cole, A. 2017. Towards an indigenous transdisciplinarity. Transdisciplinary Journal of Engineering \& Science 8 (2017): 127-150. https://doi.org/10.22545/2017/00091.

Conti, T. 2010. Systems thinking in quality management [article]. TQM Journal 22 (4): 352-368. https:// doi.org/10.1108/17542731011053280.

Costanza, R., R. d'Arge, R. de Groot, S. Farber, M. Grasso, B. Hannon, K. Limburg, S. Naeem, R.V. O’Neill, J. Paruelo, R.G. Raskin, P. Sutton, and M. van den Belt. 1997. The value of the world's ecosystem services and natural capital. Nature 387 (6630): 253-260. https://doi.org/10.1038/387253a0. 
Costanza, R., R. de Groot, L. Braat, I. Kubiszewski, L. Fioramonti, P. Sutton, S. Farber, and M. Grasso. 2017. Twenty years of ecosystem services: How far have we come and how far do we still need to go? Ecosystem Services 28 (2017): 1-16. https://doi.org/10.1016/j.ecoser.2017.09.008.

Craig, R., R. Taonui, and S. Wild. 2012. The concept of taonga in Māori culture: Insights for accounting. Accounting, Auditing \& Accountability Journal 25 (6): 1025-1047. https://doi.org/10.1108/09513 571211250233.

Cram, F. 1993. Ethics in Maori research: Working paper. In Cultural justice and ethics: Proceedings of a symposium held at the annual conference of the New Zealand psychological society, University of Victoria, ed. L.W. Nikora, 28-30. University of Waikato.

Crane, A., A. McWilliams, D. Matten, J. Moon, and D.S. Siegel. 2008. The Oxford handbook of corporate social responsibility. 1st ed. Oxford University Press.

Cunningham, C., and F. Stanley. 2003. Indigenous by definition, experience, or world view. BMJ (Clinical Research Ed.) 327 (7412): 403-404 https://www.jstor.org/stable/25455311.

Curry, J.A., H. Donker, and P. Michel. 2016. Social entrepreneurship and indigenous people. Journal of Cooperative Organization and Management 4 (2): 108-115. https://doi.org/10.1016/j.jcom.2016.09.002.

Dacin, M.T., P.A. Dacin, and P. Tracey. 2011. Social entrepreneurship: A critique and future directions. Organization Science 22 (5): 1203. https://doi.org/10.1287/orsc.1100.0620.

Dalziel, P., C. Saunders, and J. Saunders. 2018. Wellbeing economics: The capabilities approach to prosperity. Palgrave Macmillan.

Dana, L.-P. 2015. Indigenous entrepreneurship: An emerging field of research. International Journal of Business and Globalisation 14 (2): 158-169.

Davies, S. 2011. Kaumatuatanga: Roles of kaumatua and future directions. Australian Journal of Psychology 58 (S1): 128. https://doi.org/10.1080/00049530600940019.

De Bruin, A., and S. Teasdale. 2019. A research agenda for social entrepreneurship. Edward Elgar.

De Munck, B., and D. Lyna, eds. 2015. Concepts of value in European material culture. 1st ed, 1500-1900. Ashgate.

Dell, K.M. 2017. Te hokinga ki te ūkaipō: Disrupted Māori management theory: Harmonising whānau conflict in the Māori land trust doctor of philosophy. University of Auckland.

Dell, K. M., Mika, J. P., \& Warren, L. (2017). Indigenous entrepreneurial ecosystems: A New Zealand perspective Academy of Management, 4-8 August 2017. https://my.aom.org/ProgramDocs/2017/pdf/ AOM_2017_Annual_Meeting_Program.pdf

Dell, K.M., N. Staniland, and A. Nicholson. 2018. Economy of Mana: Where to next? MAI Journal 7 (1): 51-65. https://doi.org/10.20507/MAIJournal.2018.7.1.5.

Diener, E., and M.E.P. Seligman. 2004. Beyond money: Toward an economy of well-being. Psychological Science in the Public Interest 5 (1): 1-31.

Dobb, M. 1973. Theories of value and distribution since Adam Smith: Ideology and economic theory. 1st ed. Cambridge University Press.

Durie, M.H. 1999. Kaumātuatanga. Reciprocity: Māori elderly and whānau. New Zealand Journal of Psychology 28 (2): 102-106 https://www.psychology.org.nz/journal-archive/NZJP-Vol282-1999-6-Durie1.pdf.

Durie, M.H. 2002. Universal provision, indigeneity and the treaty of Waitangi. Victoria University of Wellington Law Review 24 (2002): 1-9 http://www.nzlii.org/nz/journals/VUWLawRw/2002/24.html.

Durie, M.H. 2003. Contemporary Māori development: Issues and broad directions. In In Ngā kahui pou: Launching Māori Futures, 1st ed., 87-103. Huia.

Durie, M.H. 2011. Ngā tini whetū: Navigating Māori futures. Huia.

Durie, E. T., Latimer, G. S., \& Basil, P. (1986). Report of the Waitangi Tribunal on the te reo Maori claim. https://forms.justice.govt.nz/search/Documents/WT/wt_DOC_68482156/Report\%20on\%20the\% 20Te\%20Reo\%20Maori\%20Claim\%20W.pdf

Everard, M. 2011. Sustainability and sustainable development. In Environmental management in organizations: The IEMA handbook, ed. J. Brady, A. Ebbage, and R. Lunn, 2nd ed., 39-61. Earthscan.

Firth, R. 1929. Primitive economics of the New Zealand Māori. 2nd ed. Routledge.

Foucault, M. 1972. The archaeology of knowledge. Tavistock Publications.

Frank, P.M., G.E. Shockley, and R. Stough, eds. 2008. Non-market entrepreneurship: Interdisciplinary approaches. Edward Elgar.

Frederick, H.H., and E. Henry. 2004. Innovation and entrepreneurship among Pākehā and Māori in New Zealand. In Ethnic entrepreneurship: Structure and process, ed. K. Stiles and C. Galbraith, 115-140. Elsevier Science.

Friedman, M. 1982. Capitalism and freedom. 2nd ed. University of Chicago Press.

Galperin Bella, L., M. Chavan, and S. Muhidin. 2021. Indigenous entrepreneurs in Australia: Past, present, and future. In Clan and tribal perspectives on social, economic and environmental sustainability, ed. C.S. James, M. Adela, and M. Mark, 35-47. Emerald Publishing Limited. https://doi.org/10.1108/ 978-1-78973-365-520211006. 
Grimes, A., L. Oxley, and N. Tarrant. 2012. Does money buy me love? Testing alternative measures of national wellbeing [Motu working paper]. Motu Working Paper https://www.otago.ac.nz/economics/ news/otago07840511111111111111.pdf.

Gugler, K. 2001. Corporate governance and economic performance. Oxford University Press.

Gutierrez, S. (2018). An Indigenous approach to community wealth building: A Lakota translation. https:// democracycollaborative.org/learn/publication/indigenous-approach-community-wealth-buildinglakota-translation

Haar, J., W.J. Martin, K. Ruckstuhl, D. Ruwhiu, U. Daellenbach, and A. Ghafoor. 2021. A study of Aotearoa New Zealand enterprises: How different are indigenous enterprises? Journal of Management \& Organization 27 (4): 736-750. 1-15. https://doi.org/10.1017/jmo.2021.6.

Hall, C.M. 2019. Constructing sustainable tourism development: The 2030 agenda and the managerial ecology of sustainable tourism. Journal of Sustainable Tourism 27 (7): 1044-1060. https://doi.org/10. 1080/09669582.2018.1560456.

Hanita, J., Te Kanawa, R., \& Rihia, J. (2016). Māui rau: Adapting in a changing world. https://assets.kpmg/ content/dam/kpmg/pdf/2016/05/KPMG-Maui-Rau-nz-v4.pdf

Harmsworth, G. R. (2005). Report on the incorporation of traditional values/tikanga into contemporary Māori business organisation and process. https://www.landcareresearch.co.nz/uploads/public/resea rchpubs/Harmsworth_report_trad_values_tikanga.pdf

Harris, L.D., and J. Wasilewski. 2004. Indigeneity, an alternative worldview: Four R's (relationship, responsibility, reciprocity, redistribution) vs. two P's (power and profit). Sharing the journey towards conscious evolution. Systems research and Behavioural. Science 21 (5): 489-503. https://doi.org/10. 1002/sres.631.

Harrison, D. (2020). Te tirohanga whānui: Iwi investment insights. ANZ.

Hayek, F. 1945. The use of knowledge in society. The American Economic Review 35 (4): 519-530 https:// www.jstor.org/stable/1809376.

Healy, J. 2003. Corporate governance and wealth creation in New Zealand. Dunmore Press.

Hēnare, M. 2001. Tapu, Mana, mauri, hau, wairua: A Māori philosophy of vitalism and cosmos. In Indigenous traditions and ecology, ed. J.A. Grim, 197-221. Harvard University Press.

Hēnare, M. 2003. The changing images of nineteenth century Māori society: From tribes to nation [doctor of philosophy in Māori studies]. Victoria University.

Hēnare, M. 2011. Lasting peace and the good life: Economic development and the 'āta noho' principle of Te Tiriti o Waitangi. In Always speaking: The treaty of Waitangi and public policy, ed. V.M.H. Tawhai and K. Gray-Sharp, 261-276. Huia.

Hēnare, M. 2014. The economy of Mana. In Beyond the free market: Rebuilding a just society in New Zealand, ed. D. Cooke, C. Hill, P. Baskett, and R. Irwin, 65-69. Dunmore.

Hēnare, M. 2016. In search of harmony: Indigenous traditions of the Pacific and ecology. In Routledge handbook of religion and ecology, ed. W.J. Jenkins, M.E. Tucker, and J. Grim. Routledge.

Hēnare, M. 2018. "Ko te hau tēnā o tō taonga...": The words of Ranapiri on the spirit of gift exchange and economy. Journal of the Polynesian Society 127 (4): 451-463. https://doi.org/10.15286/jps.127.4.451-463.

Henry, E., and L.-P. Dana. 2019. Māori indigenous research: Impacting social enterprise and entrepreneurship. In A research agenda for social entrepreneurship, ed. A. De Bruin and S. Teasdale, 128-135. Edward Elgar.

Henry, E., and H. Pene. 2001. Kaupapa Māori: Locating indigenous ontology, epistemology and methodology in the academy. Organization 8 (2): 234-242. https://doi.org/10.1177/1350508401082009.

Hicks, J. 1939. Value and capital: An inquiry into some fundamental principles of economic theory. 1 st ed. Oxford University Press.

Higgins, R., P. Rewi, and V. Olsen-Reeder. 2014. The value of the Māori language: Te hua o te reo Māori. Huia.

Hikuroa, D. 2017. Mātauranga Māori-The ūkaipō of knowledge in New Zealand. Journal of the Royal Society of New Zealand 47 (1): 5-10. https://doi.org/10.1080/03036758.2016.1252407.

Hindle, K., and P.W. Moroz. 2009. Indigenous entrepreneurship as a research field: Developing a definitional framework from the emerging canon. International Entrepreneurship and Management Journal 6: 357-385. https://doi.org/10.1007/s11365-009-0111-x.

Hobson, J.M., and A. Sajed. 2017. Navigating beyond the eurofetishist frontier of critical IR theory: Exploring the complex landscapes of non-western agency. International Studies Review 19 (4): 547-572. https://doi.org/10.1093/isr/vix013.

Houkamau, C.A., and C. Sibley. 2019. The role of culture and identity for economic values: A quantitative study of Māori attitudes. Journal of the Royal Society of New Zealand 49 (S1): 118-136. https://doi. org/10.1080/03036758.2019.1650782.

Houkamau, C.A., C. Sibley, and M. Hēnare. 2019. Te rangahau o te tuakiri Māori me ngā waiaro ā-pūtea: The Māori identity and financial attitudes study (MIFAS): Background, theoretical orientation and 
first wave response rates. MAI Journal 8 (2): 142-158. https://doi.org/10.20507/MAIJournal.2019.8. 2.4 .

Huambachano, M. 2015. The ayni principle: An indigenous theory of value creation. In Indigenous spiritualities at work: Transforming the spirit of enterprise, ed. C. Spiller and R. Wolfgramm, 99-115. Information Age Publishing.

Hudson, M. (2005). A Māori perspective on ethical review in (health) research Traditional Knowledge and Research Ethics Conference 10-12 June 2004, Te Papa Tongarewa.

Hudson, M., M. Roberts, L.T. Smith, M. Hemi, and S.-J. Tiakiwai. 2010. Dialogue as a method for evolving mātauranga Māori: Perspectives on the use of embryos in research. AlterNative: An International Journal of Indigenous Peoples 6 (1): 54-65 https://hdl.handle.net/10289/6375.

Hudson, M., A. Thompson, P. Wilcox, J.P. Mika, C. Battershill, M. Stott, R.T. Brooks, and L. Warbrick. 2021. Te nohonga kaitiaki: Guidelines for genomic research on taonga species. University of Waikato https://sites.massey.ac.nz/teaurangahau/wp-content/uploads/sites/53/2021/10/TNKGuidelines.pdf.

Hyden, G. 1980. Beyond Ujamaa in Tanzania: Underdevelopment and an uncaptured peasantry. 1st ed. Heinemann.

Katene, S., and R. Taonui. 2018. Conversations about indigenous rights: The UN declaration on the rights of indigenous people in Aotearoa New Zealand. Massey University Press.

Kawharu, I.H. 1989. Waitangi: Maori and Pakeha perspectives of the treaty of Waitangi. Oxford University Press.

Kawharu, M., and P. Tapsell. 2019. Whāriki: The growth of Māori community entrepreneurship. Oratia.

Kayseas, B., B. Schneider, R. Pasap, M. Gordon, and B. Anderson. 2017. Indigenous rights capital: The basis for sustainable enterprise creation. In Indigenous aspirations and rights: The case for responsible business and management, ed. A.K. Verbos, E. Henry, and A.M. Peredo, 1st ed., 62-75. Routledge.

Kickul, J.R., and T.S. Lyons. 2020. Understanding social entrepreneurship: The relentless pursuit of mission in an ever changing world. 3rd ed. Routledge.

Kingi, T. (2008). Maori landownership and land management in New Zealand. In Australian Agency for International Development (Ed.), Making land work volume two: Case studies on customary land and development in the Pacific (Vol. 2, pp. 129-152). Department of Foreign Affairs and Trade. https:// www.sprep.org/att/IRC/eCOPIES/Pacific_Region/251.pdf

Knox, C. (2005). Whakapūmau te mauri: Values-based Māori organisations [Doctor of Philosophy, Massey University].

Knudtson, P., and D. Suzuki. 1997. Wisdom of the elders. 2nd ed. Allen \& Unwin.

Kovach, M. 2010. Indigenous methodologies. Toronto University Press.

Laasch, O., R. Suddaby, R.E. Freeman, and D. Jamali. 2020. Research handbook of responsible management. Edward Elgar.

Lévi-Strauss, C. 2014. Selections from the introduction to the work of Marcel Mauss. In The logic of the gift: Toward an ethic of generosity, ed. A.D. Schrift, 45-69. Routledge.

Lidell, H., and R. Scott. 2010. An intermediate Greek-English lexicon: Founded upon the seventh edition of Liddell and Scott's Greek-English lexicon. Oxford University Press.

Lightfoot, S.R. 2016. Global indigenous politics: A subtle revolution. Routledge.

Love, M., and P. Waa. 1997. Maori in the period of colonisation. In Business and New Zealand society, ed. J. Deeks and P. Enderwick, 245-254. Longman Paul.

Macpherson, W.G., A. Tretiakov, J.P. Mika, and C. Felzensztein. 2021. Indigenous entrepreneurship: Insights from Chile and New Zealand. Journal of Business Research 127 (2): 77-84. https://doi.org/ 10.1016/j.jbusres.2021.01.013.

Mahuika, A. 1981. Leadership: Inherited and achieved. In Te ao hurihuri: The world moves on, ed. M. King, 42-63. Longman Paul.

Marglin, S.A. 1990. Towards the decolonization of the mind. In Dominating knowledge: Development, culture, and resistance, ed. F. Apffel-Marglin and S. Marglin, 1-28. Clarendon Press.

Marsden, M. 1992. God, man and universe: A Maori view. In Te ao hurihuri: Aspects of Māoritanga, ed. M. King, 1st ed., 117-137. Reed.

Mauss, M. 2002. The gift: The form and reason for exchange in archaic societies. 3rd ed. Routledge.

Mead, A.T.P. 1994. Ngā tikanga, ngā taonga: Cultural and intellectual property rights of indigenous peoples. Unversity of Auckland and International Research Institute of Māori and Indigenous Education.

Mead, H.M. 2003. Tikanga Māori: Living by Māori values. Huia.

Mead, H.M. 2012. Understanding mātauranga Māori. In Conversations on mātauranga Māori, ed. T. Black, D. Bean, W. Collings, and W. Nuku, 9-14. New Zealand Qualifications Authority https://www.nzqa. govt.nz/assets/Maori/ConversationsMMv6AW-web.pdf.

Meade, R.. (2021). Exploring the cultural value of kapa haka - the Mãaori performing arts - using a binomial logit and other travel cost models. https://cedf2c8a-aefa-4f90-be62-efeee5080c3f.filesusr.com/ ugd/022795_88139eda10574897bc1561f19f2bb577.pdf 
Meijl, T.V. 2012. Changing property regimes in Māori society: A critical assessment of the settlement process. Journal of the Polynesian Society 121 (2): 181-208. https://doi.org/10.15286/jps.121.2.181-208.

Mignolo, W.D. 2009. Epistemic disobedience, independent thought and decolonial freedom. Theory, Culture and Society 26 (7-8): 159-181. https://doi.org/10.1177/0263276409349275.

Mika, C.T.H. 2012. Overcoming 'being' in favour of knowledge: The fixing effect of 'mātauranga'. Educational Philosophy and Theory 44 (10): 1080-1092. https://doi.org/10.1111/j.1469-5812.2011. 00771.x.

Mika, J. P. (2014). Manaakitanga: Is generosity killing Māori enterprises? In P. Davidsson (Ed.), Proceedings of the Australian Centre for Entrepreneurship Research Exchange Conference 4-7 February 2014, UNSW, Sydney, Australia (pp. 815-829). Queensland University of Technology.

Mika, J. P. (2015). The role of publicly funded enterprise assistance in Māori entrepreneurship in Aotearoa New Zealand [Doctor of Philosophy, Massey University].

Mika, J.P. 2016. The role of elders in indigenous economic development: The case of kaumātua in Māori enterprises of Aotearoa New Zealand. In Indigenous people and economic development: An international perspective, ed. K. Iankova and A. Hassan, 151-176. Gower.

Mika, J.P. 2020. Indigenous entrepreneurship: How indigenous knowing, being and doing shapes entrepreneurial practice. In Entrepreneurship: A contemporary \& global approach, ed. D. Deakins and J.M. Scott, 1-32. Sage https://study.sagepub.com/deakins/student-resources/e-chapter-on-indig enous-entrepreneurship.

Mika, J.P., R. Colbourne, and S. Almeida. 2020. Responsible management: An indigenous perspective. In Research handbook of responsible management, ed. O. Laasch, R. Suddaby, E. Freeman, and D. Jamali, 260-276. Edward Elgar.

Mika, J.P., N. Fahey, and J. Bensemann. 2019. What counts as an indigenous enterprise? Evidence from Aotearoa New Zealand. Journal of Enterprising Communities: People and Places in the Global Economy 13 (3): 372-390. https://doi.org/10.1108/JEC-12-2018-0102.

Mika, J.P., and J.G. O'Sullivan. 2014. A Māori approach to management: Contrasting traditional and modern Māori management practices in Aotearoa New Zealand. Journal of Management \& Organization 20 (5): 648-670. https://doi.org/10.1017/jmo.2014.48.

Mika, J.P., L. Warren, D. Foley, and F.R. Palmer. 2017. Perspectives on indigenous entrepreneurship, innovation and enterprise. Journal of Management \& Organization 23 (6): 767-773. https://doi. org/10.1017/jmo.2018.4.

Moorfield, J. C. (2011). Te aka: Mana. https://maoridictionary.co.nz/search?idiom=\&phrase=\&prove $\mathrm{rb}=\&$ loan $=\&$ histLoanWords $=\&$ keywords $=$ mana

Moorfield, J. C. (2021). Te aka: Hau. https://maoridictionary.co.nz/search?idiom=\&phrase=\&proverb= \&loan $=$ \&histLoanWords $=\&$ keywords $=$ hau

Mrabure, R.H.O., D. Ruwhiu, and B. Gray. 2018. Indigenous entrepreneurial orientation: A Māori perspective. Journal of Management \& Organization 27 (1): 62-86. https://doi.org/10.1017/jmo.2018.43.

Nana, G., A. Reid, H. Schulze, H. Dixon, S. Green, and H. Riley. 2021. Te ōhanga Māori 2018. The Māori economy 2018 https://berl.co.nz/sites/default/files/2021-01/Te\%20\%C5\%8Changa\%20M\% C4\%81ori\%202018.pdf.

Nicholson, A. 2019. Hau: Giving voices to the ancestors. Journal of the Polynesian Society 128 (2): 137-162. https://doi.org/10.15286/jps.128.2.137-162.

Orange, C. 1987. The treaty of Waitangi. Allen \& Unwin.

Parker, S.C. 2009. The economics of entrepreneurship. 1st ed. Cambridge University Press.

Peredo, A.M., R.B. Anderson, C.S. Galbraith, B. Honig, and L.-P. Dana. 2004. Towards a theory of indigenous entrepreneurship. International Journal of Entrepreneurship and Small Business 1 (1-2): 1-20.

Petrie, H. 2006. Chiefs of industry: Māori tribal enterprise in early colonial New Zealand. Auckland University Press.

Podolny, J.M., and M. Hill-Popper. 2004. Hedonic and transcendent conceptions of value. Industrial and Corporate Change 13 (1): 91-116. https://doi.org/10.1093/icc/13.1.91.

Polanyi, K. 1944. The great transformation: The political and economic origins of our time. 1st ed. Farrar \& Rinehart.

Potae, K. (2020). Māori business: Survey report 2020. https://www.bdo.nz/getmedia/d756d8ed-759d4943-8768-915c1cfe1fb7/Maori-Business-Report-2020-FINAL_1.pdf.aspx

Powick, K. 2003. Māori research ethics: A literature review of the ethical issues and implications of kaupapa Māori research and research involving Māori for researchers, supervisors and ethics committees. University of Waikato.

Ranis, G., F. Stewart, and A. Ramirez. 2000. Economic growth and human development. World Development 28 (2): 197-219 http://www.econ.yale.edu/ granis/papers/cp0546.pdf. 
Ratten, V. 2007. Entrepreneurship as social change: A third movements in entrepreneurship book. Journal of Enterprising Communities: People and Places in the Global Economy 1 (3): 285-285. https://doi.org/10.1108/17506200710779576.

Reed, A.W., and R. Calman. 2021. He atua he tangata: The world of Māori mythology. 3rd ed. Oratia.

Reid, J., and M. Rout. 2016. Māori tribal economy: Rethinking the original economic institutions. In Unlocking the wealth of tribal nations, ed. T.L. Anderson, 84-103. Lexington Books.

Reid, J., and M. Rout. 2020. The implementation of ecosystem-based management in New Zealand - A Māori perspective. Marine Policy 117 (2020): 1-6. https://doi.org/10.1016/j.marpol.2020.103889.

Reid, J., M. Rout, J.P. Mika, A. Gillies, D. Ruwhiu, and S. Awatere. 2019. Whenua, life, values programme: Report four-Testing a values-centred decision-support tool for Māori agribusiness. University of Canterbury Ngāi Tahu Research Centre.

Reid, J., M. Rout, J. Whitehead, and T.P. Katene. 2021. Tauutuutu: White paper executive summary. Our Land and Water National Science Challenge https://ourlandandwater.nz/wp-content/uploads/2021/ 08/Tauutuutu_WhitePaper_ExecutiveSummary.pdf.

Roser, M., \& Ortiz-Ospina, E. (2019). Global extreme poverty. https://ourworldindata.org/extreme-poverty

Roskruge, M., Morrison, S., \& Maxwell, T. K. (2017). Measuring the value of the contribution of Māori language and culture to the New Zealand economy. http://www.tetaurawhiri.govt.nz/assets/Uploa ds/Measure-the-value-of-te-reo-Maori2.pdf

Rout, M., S. Awatere, J.P. Mika, J. Reid, and M. Roskruge. 2021. A Māori approach to environmental economics: Te ao tūroa, te ao hurihuri, te ao mārama-The old world, a changing world, a world of light. Oxford Research Encyclopedia of Environmental Science. https://doi.org/10.1093/acref ore/9780199389414.013.715.

Rout, M., Lythberg, B., Mika, J. P., Gillies, A., Bodwitch, H., Hikuroa, D., Awatere, S., Wiremu, F., Rakena, M., \& Reid, J. (2019). Kaitiaki-centred business models: Case studies of Māori marine-based enterprises in Aotearoa New Zealand. https://www.sustainableseaschallenge.co.nz/tools-and-resources/ kaitiaki-centred-business-models-case-studies-of-maori-marine-based-enterprises-in-aotearoa-nz/

Rout, M., J. Reid, H. Bodwitch, A. Gillies, B. Lythberg, D. Hikuroa, L. Mackey, S. Awatere, J.P. Mika, F. Wiremu, M. Rakena, and K. Davies. 2018. Māori marine economy: A review of the literature concerning the historical and contemporary structure of the Mäori marine economy. 1st ed. Massey University.

Rout, M., J. Reid, and J. Mika. 2020. Māori agribusinesses: The whakapapa network for success. AlterNative: An International Journal of Indigenous Peoples 16 (3): 193-201. https://doi.org/10.1177/ 1177180120947822.

Royal, T.A.C. 2003. The woven universe: Selected writings of rev Māori Marsden. Estate of Rev Māori Marsden.

Royal, T. A. C. (2005). An organic arising: An interpretation of tikanga based upon the Māori creation traditions Tikanga Rangahau Mātauranga Tuku Iho: Traditional Knowledge and Research Ethics Conference, 10-12 June 2004, Te Papa Tongarewa.

Russell, B. 2004. History of Western philosophy. 2nd ed. Routledge.

Ryan, R.M., and E.L. Deci. 2001. On happiness and human potentials: A review of research on hedonic and eudaimonic well-being. Annual Review of Psychology 52 (1): 141-166. https://doi.org/10. 1146/annurev.psych.52.1.141.

Sahlins, M.D. 1972. Stone age economics. 1st ed. Aldine.

Schulze, H., Hurren, K., \& Riley, H. (2021). Case studies on advancing inclusive economic growth: Understanding and valuing Indigenous economies within APEC. https://www.apec.org/Publicatio ns/2021/04/Case-Studies-on-Advancing-Inclusive-Economic-Growth

Schumpeter, J.A. 2000. Entrepreneurship as innovation. In The social science view, ed. R. Swedberg, 51-75. Oxford University Press.

Sciascia, A., Hall, T., Roskruge, M., \& Mika, J. P. (2019). He whenua tipu: Transformation of Māori agribusiness and the fourth industrial revolution (4IR) report. https://mro.massey.ac.nz/bitstream/ handle/10179/15927/Sciascia\%20et\%20al-2019.pdf?sequence=1\&isAllowed=y

Sen, P. 2003. Changing tribal life: A socio-philosophical perspective. Concept Publishing.

Shirodkar, S. (2021). Unlocking Indigenous entrepreneurial potential: A mixed methods study of the pathways and barriers into business for Indigenous Australians [Doctor of Philosophy, Australian National University].

Smallbone, D. 2010. Entrepreneurship and public policy. 2nd ed. Edward Elgar.

Smith, A. 1991. The wealth of nations. David Campbell.

Smith, G.H. 1992. Tane-Nui-a-Rangi's legacy ... Propping up the sky: Kaupapa Maori as resistance and intervention new Zealand Association for Research in education/Australia Association for Research in education joint conference. Deakin University. 
Smith, L.T. 1999. Decolonizing methodologies: Research and indigenous peoples. 1st ed. Zed Books.

Smith, G.H., T.K. Hoskins, and A. Jones. 2012. Kaupapa Māori: The dangers of domestication. New Zealand Journal of Educational Studies 47 (2): 10-20 http://www.hauhake.auckland.ac.nz/record/ 197137.

Smith, G.H., R.S. Tinirau, A. Gillies, and V.C.A. Warriner. 2015. He mangōpare amohia: Strategies for Māori economic development. Te Whare Wānanga o Awanuiārangi http://www.maramatanga.ac.nz/ sites/default/files/He\%20Mangopare\%20Amohia_0.pdf.

Spiller, C., R.M. Wolfgramm, E. Henry, and R. Pouwhare. 2020. He pūrongo poto: Ko te hautūtanga Māori me te whakatau tikanga whaihua kia houkura ngā ōhanga me te oranga tonutanga: A short report on effective Māori leadership and decision-making for prosperous economies of wellbeing. Ngā Pae o te Māramatanga.

Stewart, G. 2017. The 'hau' of research: Mauss meets kaupapa Māori. Journal of World Philosophies 2 (Summer): 1-11. https://doi.org/10.2979/jourworlphil.2.1.01.

Stiglitz, J.E., A.K. Sen, and J.-P. Fitoussi. 2010. Mismeasuring our lives: Why GDP doesn't add up. The New Press.

Suddaby, R., M. Ganzin, and A. Minkus. 2017. Craft, magic and the re-enchantment of the world. European Journal of Management 23 (2017): 285-296. https://doi.org/10.1016/j.emj.2017.03.009.

Tawhai, V.M.H., and K. Gray-Sharp. 2011. 'Always Speaking' the treaty of Waitangi and public policy. Huia.

Te Momo, O.H.F. 2007. Biotechnology: The language of multiple views in Māori communities. Biotechnology Journal 2 (9): 1179-1183. https://doi.org/10.1002/biot.200700123.

Trosper, R. 2009. Resilience, reciprocity and ecological economics: Northwest coast sustainability. 1st ed. Routledge.

United Nations. (2019). Global environment outlook. https://www.unenvironment.org/resources/globalenvironment-outlook-6

Verbos, A.K., E. Henry, and A.M. Peredo. 2017. Indigenous aspirations and rights: The case for responsible business and management. 1st ed. Routledge.

Waa, P., and M. Love. 1997. The pre-European Maori economy. In Business and New Zealand society, ed. J. Deeks and P. Enderwick, 15-32 Longman Paul.

Watene, K. 2016. Valuing nature: Māori philosophy and the capability approach [article]. Oxford Development Studies 44 (3): 287-296. https://doi.org/10.1080/13600818.2015.1124077.

Watene, K., and J. Drydyk. 2016. Theorizing justice: Critical insights and future directions. Rowman \& Littlefield.

Weijers, D., \& Mukherjee, U. (2016). Living standards, wellbeing, and public policy: Background paper for He Tirohanga Mokopuna 2016 Statement on the Long-Term Fiscal Position. http://www.treasury. govt.nz/government/longterm/fiscalposition/2016/ltfs-16-bg-lswpp.pdf

Wheen, N.R., and J. Hayward. 2012. Treaty of Waitangi settlements. 1st ed. Bridget Williams.

Wiklund, J., P. Davidsson, D.B. Audretsch, and C. Karlsson. 2011. The future of entrepreneurship research. Entrepreneurship Theory and Practice 35 (1): 1-9. https://doi.org/10.1111/j.1540-6520.2010. 00420.x.

Williams, J. V., Kearney, R., Maaka, R., Ringwood, P., \& Walker, K. (2011). Ko Aotearoa tēnei: A Report into claims concerning New Zealand law and policy affecting Māori culture and identity - Te taumata tuatahi (Volume 1). https://forms.justice.govt.nz/search/Documents/WT/wt_DOC_68356054/KoAot earoaTeneiTT1W.pdf

Wilson, S. 2008. Research is ceremony: Indigenous research methods. 1st ed. Fernwood.

Winiata, W. 1988. Hapu and iwi resources and their quantification. In The April report: Vol III part two future directions: Report of the Royal Commission on social policy: Te Kömihana a te Karauna mō ngā Āhuatanga-ā-iwi: April 1988, ed. I. Richardson, L. Cook, M.H. Durie, A. Ballin, M. Bruce, and R. Noonan, 789-803. Royal Commission on Social Policy.

Winiata, V. 2008. Improving the development of Māori assets: A discussion paper for the Māori property rights conference 2008. Confrenz Ltd. https://winiata.co.nz/pdfs/Maori_Property_Rights_Paper_ (July\%202008).pdf.

Wolfgramm, R., Spiller, C., Henry, E., \& Pouwhare, R. (2019). A culturally derived framework of valuesdriven transformation in Māori economies of well-being (Ngā hono ōhanga oranga). AlterNative: An International Journal of Indigenous Peoples, 1-11. https://doi.org/10.1177/1177180119885663.

World Bank. (2019). Indigenous peoples. https://www.worldbank.org/en/topic/indigenouspeoples

Zapalska, A., G. Perry, and H. Dabb. 2003. Maori entrepreneurship in the contemporary business environment. Journal of. Developmental Entrepreneurship 8 (3): 219-235.

Publisher's Note Springer Nature remains neutral with regard to jurisdictional claims in published maps and institutional affiliations. 
Jason Paul Mika Associate Professor Jason Paul Mika's tribal affiliations are Tūhoe, Ngāti Awa, Whakatōhea, and Ngāti Kahungunu. Dr. Mika is an associate professor at Massey University's School of Management and a director of Te Au Rangahau, Massey Business School's Māori business research centre. Dr. Mika's research centres on intersections of indigeneity and entrepreneurship in multiple sites, sectors and scales.

Kiri Dell Dr. Kiri Dell's tribal affiliation is Ngāti Porou. Dr. Dell is a senior lecturer in the University of Auckland's Faculty of Business and Economics, academic director of the Post Graduate Diploma in Maori Business Development and co-chair of the Native and Indigenous Caucus of the Academy of Management. Dr. Dell's research focuses on Māori land development and Indigenous entrepreneurship.

Jamie Newth Dr. Jamie Newth's tribal affiliation is Ngāpuhi. Dr. Newth is a lecturer in the University of Auckland's Faculty of Business and Economics, where he teaches Māori business strategy, entrepreneurship and entrepreneurial ecosystems. Dr. Newth's research focuses on social entrepreneurship, impact investing, and Māori entrepreneurship.

Carla Houkamau Professor Carla Houkamau is of Ngāti Porou, Ngāti Kahungunu, Ngāi Tahu and Pākehā descent. Dr. Houkamau is a professor in the Department of Management and International Business, the director of the Mira Szászy Research Centre for Māori and Pacific Economic Development, and Deputy Dean, University of Auckland Business School. Dr. Houkamau leads Te Rangahau o Te Tuakiri Māori me Ngā Waiaro ā-Pūtea I The Māori Identity and Financial Attitudes Study. 